\title{
Leaf Beetles (Coleoptera: Chrysomelidae) of Tehran, Alborz and Qazvin Provinces, Iran
}

\author{
M. MIRZAEI, J. NOZARI* and V. H. NAVEH \\ Department of Plant Protection, College of Agriculture, University of Tehran, Karaj, Iran
}

(Received: 13 April 2015; accepted: 8 June 2015)

\begin{abstract}
A faunistic survey of leaf beetles (Chrysomelidae) was accomplished in Tehran, Alborz and Qazvin provinces of Iran, during 2012 and 2013. In total, 30 species belong to five subfamilies (Chrysomelinae, Cryptocephalinae, Galerucinae, Cassidinae and Criocerinae) and 22 genera were identified.
\end{abstract}

Keywords: Coleoptera, Chrysomelidae, fauna, Iran.

Iran is one of the most diverse areas in the Palaearctic. Family Chrysomelidae with over 37,000 described species in the world is one of the largest groups of Coleoptera (Jolivet et al., 2009). Nonetheless, so many species remain to be described and can be reaching up to 60,000 species (Reid, 1995). All leaf beetles are phytophagous. In particular, so many species of them are regarded as agricultural and forest pest and some another one as biological control agents of certain weeds (Jolivet et al., 1988; Warchałowski, 1994). The Palaearctic Chrysomelidae fauna is known to comprise more than 3500 species (Jolivet and Verma, 2002; Gruev and Döberl, 2005; Konstantinov et al., 2009; Löbl and Smetana, 2010). In particular, in Turkey 770 species (81 endemic species) have been recorded (Ekiz et al., 2013). In the Balkan Peninsula, Republic of Macedonia and Romania 780, 213 and 571 species recorded, respectively (Maican, 2005; Gruev and Tomov, 2007; Rozner and Rozner, 2008). On the other hand Iranian leaf beetle fauna is poorly known. Despite of the several faunistic records based on museum, private collections and scientific expeditions that were published from Iran (Berti and Rapilly, 1973, 1976, 1977; Lopatin, 1977, 1979, 1980, 1981, 1985; Medvedev, 1983; Modarres Awal, 1997; Döberl, 2010) there are only about 500 species reported. Nevertheless, based on checklists of neighbour's countries, Iranian fauna is likely more complex and probably several species are still remaining unknown.

\section{Materials and Methods}

Based on the climate variability of Tehran, Alborz and Qazvin provinces, the area situated in Irano-Touranian semi-arid mountains, located in central part of Alborz Moun-

\footnotetext{
*Corresponding author; e-mail: nozari@ut.ac.ir
} 


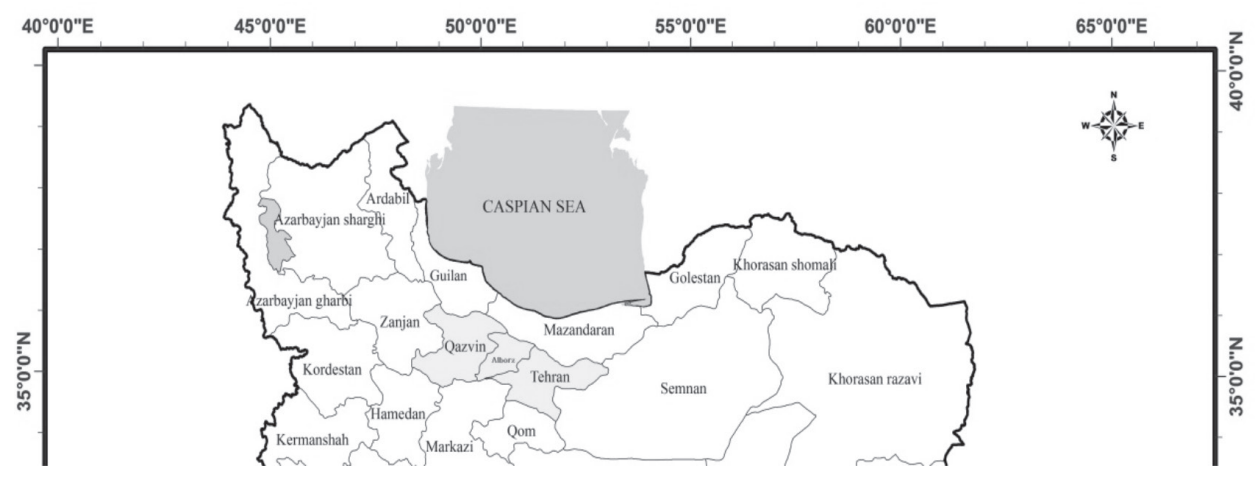

Fig. 1. Specimens were collected from highlighted places in the map as Tehran, Alborz and Qazvin provinces, Iran

tains was selected. To achieve a good knowledge of leaf beetles inhabiting Tehran, Alborz and Qazvin provinces several field trips were recognized to collect specimens from 2012 to 2013. This area located between $34^{\circ} 55^{\prime}$ to $36^{\circ} 45^{\prime} \mathrm{N}$ (Fig. 1). The localities belong to provinces of Iran are as follows (degree of latitude and longitude are in brackets): Alborz province: Abasabad city $\left(35^{\circ} 57^{\prime} \mathrm{N} / 51^{\circ} 02^{\prime} \mathrm{E}\right)$, Asara village, Karaj city $\left(36^{\circ} 01^{\prime}\right.$ $\left.\mathrm{N} / 51^{\circ} 11^{\prime} \mathrm{E}\right)$, Eshtehard city $\left(35^{\circ} 40^{\prime} \mathrm{N} / 50^{\circ} 33^{\prime} \mathrm{E}\right)$, Hashtgerd city (35 $\left.58^{\prime} \mathrm{N} / 50^{\circ} 39^{\prime} \mathrm{E}\right)$, Karaj city E); Qazvin province: Alamout region $\left(36^{\circ} 57^{\prime} \mathrm{N} / 50^{\circ} 51^{\prime} \mathrm{E}\right)$, Avaj city $\left(35^{\circ} 34^{\prime}\right.$ $\left.\mathrm{N} / 49^{\circ} 14^{\prime} \mathrm{E}\right)$, Heiran village, Qazvin city $\left(36^{\circ} 27^{\prime} \mathrm{N} / 50^{\circ} 16^{\prime} \mathrm{E}\right)$, Qazvin city $\left(36^{\circ} 20^{\prime} \mathrm{N} / 50^{\circ} 03^{\prime}\right.$ E); Tehran province: Damavand city $\left(35^{\circ} 41^{\prime} \mathrm{N} / 52^{\circ} 10^{\prime} \mathrm{E}\right)$, Firuzkuh city $\left(35^{\circ} 41^{\prime} \mathrm{N} / 52^{\circ} 04^{\prime}\right.$ E), Lavasan city $\left(36^{\circ} 03^{\prime} \mathrm{N} / 50^{\circ} 37^{\prime} \mathrm{E}\right)$, Pakdasht city $\left(35^{\circ} 29^{\prime} \mathrm{N} / 51^{\circ} 43^{\prime} \mathrm{E}\right)$, Rey city $\left(35^{\circ} 36^{\prime}\right.$ $\left.\mathrm{N} / 51^{\circ} 28^{\prime} \mathrm{E}\right)$, Shahriar city $\left(35^{\circ} 39^{\prime} \mathrm{N} / 51^{\circ} 02^{\prime} \mathrm{E}\right)$, Varamin city $\left(35^{\circ} 20^{\prime} \mathrm{N} / 51^{\circ} 36^{\prime} \mathrm{E}\right)$.

Specimens were sweep netted, beaten and singled. All specimens were collected by M. Mirzaei. Identification was made with the aid of the original descriptions and the other main references (including the collaboration with expert in systematic of this group) (Warchałowski 2010).

\section{Results}

In the present paper 30 species belong to 22 genera and five subfamilies (Chrysomelinae, Cryptocephalinae, Galerucinae, Cassidinae and Criocerinae) are identified, of which four, two and one species are new records for Alborz, Tehran and Qazvin provinces, respectively.

Chrysomelinae Latreille, 1802

Chrysomela populi Linnaeus 1758 - 20", 3@ Karaj city, 26.VI.2012; 10", 5@ Shahriar city, 30.V.2013; 4o Qazvin city, 30.VI.2013.

Plagiodera versicolora Laicharting, 1781 - 10", 2ᄋ Nazarabad city, 23.VII.2013; 2Q Asara village, Karaj city, 12.VIII.2012. 
Gastrophysa polygoni Linnaeus, 1758 - 10", 8Q Varamin city, 8. VI.2012; 5o Pakdasht city, 8.VI.2012; 1ᄋ Alamout region, 21.VII.2012.

Chrysolina coerulans Scriba, 1791 - 10̛, 1Q Nazarabad city, 23.VII.2013; 2 ? Asara village, Karaj city, 12.VIII.2012.

Chrysolina herbacea Duftschmid, 1825 - 10', 2Q Taleqan city, 11.VII.2012. This is the first record of this species for Alborz province.

Chrysolina marginata Linnaeus, 1767 - 10", 2Q Rey city, 23.VII.2012; 3Q Eshtehard city, 18.VI.2013, 10", 4ㅇ Nazarabad city, 23.VII.2013; 3ᄋ Asara village, Karaj city, 12.VIII.2012; 10", 1Q Heiran village, Qazvin city, 28.VII.2013.

Chrysolina hyrcana Weise, 1884 - 10", 2O Firuzkuh city, 26.VI.2013. - This is the first record of this species for Tehran province.

Entomoscelis adonidis Pallas, 1771 - 20", 60 Karaj city, 26.VI.2012; 20 Abasabad city, 24.VI.2012; 30", 5o Qazvin city, 20.VII.2013; 2Q Asara village, Karaj city, 12.VIII.2012; 10', 1\% Heiran village, Qazvin city (Qazvin province), $36^{\circ} 27^{\prime}$ N/50 $10^{\circ}$ ' E, 28. VII.2013; 50", 8ᄋ Taleqan city, 11.VII.2012.

Entomoscelis suturalis Weise, 1882 - 10', 5ᄋ Firuzkuh city, 26.VI.2012; 3@ Avaj city, 17.VII.2013. - This is the first record of this species for Qazvin province.

Colaphellus sophiae Schaller, 1783 - 10", 10 Damavand city, 6.VIII.2012. This is the first record of this species for Tehran province.

Cryptocephalinae Gyllenhal, 1813

Cryptocephalus sp. - 1Q Hashtgerd city, 15.VIII.2013.

Pachybrachis scripticollis Faldermann, 1837 - 10", 1@ Eshtehard city, 12.VII.2013. - This is the first record of this species for Alborz province.

Galerucinae Latreille, 1802

Galeruca armeniaca Weise, 1886 - 10", 4ㅇ Taleqan city, 20.VI.2013; 30', 50 Shahriar city, 30.V.2013; 30", 4Q Qazvin city, 30.VI.2013.

Xanthogaleruca luteola Müller, 1766 - 30", 60 Karaj city, 26.VI.2012; 20", 30 Nazarabad city, 23.VII.2013; 20', 1@ Asara village, Karaj city, 12.VIII.2012.

Agelastica alni Linnaeus, 1758 - 10', 1ㅇ Nazarabad city, 23.VII.2013.

Aulacophora foveicollis Lucas, 1849 - 40", 5ᄋ Varamin city, 8.VI.2012; 40", 3ᄋ Pakdasht city, 8.VI.2012; 30", 7@ Karaj city, 26.VI.2012; 20", 2Q Abasabad city, 24.VI.2012; 50", 4Q Qazvin city, 20.VII.2013; 10", 1@ Heiran village, Qazvin city, 28. VII.2013; 30", 9ᄋ Taleqan city, 11.VII.2012.

Falsoexosoma cyanipennis Reitter, 1902 - 10", 2ᄋ Taleqan city, 11.VII.2012.

Nymphius stylifer Weise, 1899 - 10", 2Q Nazarabad city, 23. VII.2013.

Altica sp. - 5o Varamin city, 8.VI.2012; 30 Pakdasht city, 8.VI. 2012.

Chaetocnema hortensis Geoffroy, 1785 - 10", 5ㅇ Karaj city, 26.VI.2012; 20", 4Q Varamin city, 8.VI.2012; 3Q Pakdasht city, 8.VI.2012; 2ᄋ Taleqan city, 11.VII.2012.

Chaetocnema tibialis Illiger, 1807 - 30", 30 Varamin city, 8. VI.2012; 30', 2ᄋ Pakdasht city, 8.VI.2012; 10', 3ᄋ Karaj city, 26.VI.2012; 30', 4ㅇ Abasabad city, 24.VI.2012; 
30', 2Q Qazvin city, 20.VII.2013; 20", 4Q Heiran village, Qazvin city, 28.VII.2013; 30", 6O Taleqan city, 11.VII.2012.

Phyllotreta atra Fabricius, 1775 - 30", 4ㅇ Abasabad city, 24. VI.2012.

Psylliodes tricolor Weise, 1888 - 10', 20 Lavasan city, 22.VIII.2012. - This is the first record of this species for Alborz province.

Psylliodes persica Allard, 1867 - 20", 2Q Varamin city, 8.VI.2012; 20", 3Q Pakdasht city, 23.VII.2012. - This is the first record of this species for Alborz province.

\section{Cassidinae}

Cassida viridis Linnaeus, 1758 - 10", 1Q Lavasan city, 22.VIII.2012; 2Q Taleqan city, 11.VII.2013.

Cassida nebulosa Linnaeus, 1758 - 3Q Taleqan city, 11.VII.2013.

Cassida transcaucasica Borowiec and Swietojanska, 2001 - 1Q Damavand city, 6.VIII.2013.

Hypocassida subferruginea Schrank, 1776 - 10", 2Q Eshtehard city, 18.VI.2013; 10", 2Q Asara village, Karaj city, 12.VIII.2012;3ᄋ Heiran village, Qazvin city, 28. VII. 2013.

\section{Criocerinae}

Lilioceris faldermanni Guerin-Meneville, 1844 - 10', 2@ Nazarabad city, 23.VII.2013.

Oulema melanopus Linnaeus, 1758 - 40", 8@ Karaj city, 26. VI.2012; 20', 50 Abasabad city, 24.VI.2012; 50", 8ㅇ Varamin city, 8.VI.2012; 10", 3ㅇ Pakdasht city, 8.VI.2012; 30", 3Q Qazvin city, 20.VII.2013; 20", 4o Heiran village, Qazvin city, 28.VII.2013; 50", 12ᄋ Taleqan city, 11.VII.2012.

\section{Discussion}

During 2012 and 2013 from 20 places belonging to three provinces in total 30 species were collected, of which Taleqan city with 10 species seemed to have the most diverse leaf beetle fauna. Regarding to recent changes in classification of some group in the family Chrysomelidae, the most diversity of leaf beetles was collected form subfamily Galerucinae (consists of four tribes Alticini and Galerucini, Hylaspini, Luperini) with 12 species. Previously, Alticinae, Clytrinae and Galerucinae were separated as a distinct subfamily (Bouchard et al., 2011). Cassida transcaucasica with only one specimen were lowest abundant in the area. Additionally Aulacophora foveicollis, Chaetocnema tibialis and Oulema melanopus with most abundant are important agricultural pests. According to this study, in total with 7 new records for Alborz, Tehran and Qazvin provinces were given and based on host plants and climate diversity in the mentioned area, we believe that in this area and also in other poorly known place this research should be continued for making a comprehensive data on Chrysomelidae of Iran and findings of new records or even new species for science. 


\section{Acknowledgements}

We are very grateful to Prof. Lech Boroweic (Poland) and Dr. Ron Beenen (the Netherlands) for their help in identification and providing some valuable papers. This project was supported by the research division of the University of Tehran, Iran, which is greatly appreciated.

\section{Literature}

Berti, N. and Rapilly, M. (1973): Contribution a la faune de l'Iran; Voyages de MM. R. Naviaux et M. Rapilly (Col.: Chrysomelidae). Annales de la Societe Entomologique de France 9, 861-894.

Berti, N. and Rapilly, M. (1976): Faune d'Iran liste d'especies et revision du genre Lilioceris Reitter (Col. Chrysomelidae). Annales de la Societe Entomologique de France 12, 31-73.

Berti, N. and Rapilly, M. (1977): Remarques taxinomiques sur Aphthona alexander Berti and Rapilly (Col. Chrysomelidae, Alticinae). Annales de la Societe Entomologique de France 13, 69-74.

Bouchard, P., Bousquet, Y., Davies, A. E., Alonso-Zarazaga, M. A., Lawrence, J. F., Lyal, C. H. C., Newton, A. F., Reid, C. A. M., Schmitt, M., Ślipiński, S. A. and Smith, A. B. T. (2011): Family-group names in Coleoptera (Insecta). ZooKeys 88, 1-972.

Döberl, M. (2010): Contribution to the knowledge of the alticines from Iran, with description of a new Phyllotreta species (Col.: Chrysomelidae: Alticinae). J. Entomol. Soc. of Iran 30, 41-54.

Ekiz, A., Sen, I., Aslan, E. and Gök, A. (2013): Checklist of leaf beetles (Coleoptera: Chrysomelidae) of Turkey, excluding Bruchinae. J. Natural History 47, 1-75.

Gruev, B. and Döberl, M. (2005): General distribution of the flea beetles in the Palaearctic subregion (Coleoptera, Chrysomelidae: Alticinae). Supplement. Pensoft Series Faunistica 42, pp.1-240.

Gruev, B. and Tomov, V. (2007): A distributional atlas and catalogue of the leaf beetles of Bulgaria (Coleoptera: Chrysomelidae). Zoocartographica Balcanica Vol. 3. Sofia-Moscow, Pensoft, pp.1-350.

Jolivet, P. and Verma, K. K. (2002): Biology of Leaf Beetles. Intercept Publishers, Andover, Hampshire, pp. $1-332$.

Jolivet, P., Petitpierre, E. and Hsiao, T. H. (1988): Biology of Chrysomelidae. Kluwer Academic Publishers, Dordrecht, pp. 1-615.

Jolivet, P., Santiago-Blay, J. and Schmitt, M. (2009): Research on Chrysomelidae, Vol. 2. Brill, Leiden, pp. 1-300.

Konstantinov, A. S., Korotyaev, B. A. and Volkovitsh, M. G. (2009): Insect biodiversity in the Palearctic Region. In: Foottit, R. G. and Adler, P. H. (eds): Insect Biodiversity: Science and Society. Wiley-Blackwell, Oxford, pp. 107-162.

Lopatin, I. K. (1977): Eine neue Cryptocephalus-Art aus Iran (Coleoptera, Chrysomelidae). Mitteilungen entomologische Gesellschaft Basel, N. F. 27, 116-118.

Lopatin, I. K. (1979): New genus and new species of leaf beetles (Coleoptera, Chrysomelidae) from Iran. Review of Entomology 58, 586-589.

Lopatin, I. K. (1980): Leaf beetles (Coleoptera, Chrysomelidae) of Iran. Results of Czechoslovak-Iranian expedition 1973. I. Review of Entomology 59, 613-623.

Lopatin, I. K. (1981): New genera and species of leaf beetles from Iran. Results of Czechoslovak-Iranian expedition in 1973. Part II. Review of Entomology 60, 623-628.

Lopatin, I. K. (1985): Leaf-beetles (Coleoptera, Chrysomelidae) of Iran. Results of the Czechoslovak-Iranian Expeditions of the 1973-1977. IV. Entomologicheskoe Obozrenie 64, 760-771. (in Russian).

Löbl, I. and Smetana, A. (eds): (2010): Catalogue of Palaearctic Coleoptera, Chrysomeloidea. Apollo Books, Stenstrup, Vol. 6, pp. 337-647.

Maican, S. (2005): Checklist of Chrysomelidae (Coleoptera) in Romania. Travaux Museum National d'Histoire Nataturalle 'Grigore Antipa' 48, 119-136.

Medvedev, L. N. (1983): Chrysomelidae from Iran (Insecta: Coleoptera). Senckenbergiana Biologica 64, 133-140. 
Modarres Awal, M. (1997): Family Chrysomelidae. In: M. Modarres Awal (ed.): List of Agricultural Pests and their Natural Enemies in Iran. Ferdowsi University Press, Mashad, pp. 151-153.

Reid, C. A. M. (1995): A cladistic analysis of subfamilial relationships in the Chrysomelidae sensu lato (Chrysomeloidea). In: J. Pakaluk and S. A. Ślipiński (eds): Biology, Phylogeny and Classification of Coleoptera: Papers celebrating the 80th birthday of Roy A. Crowson. Muzeum i Instytut Zoologii PAN, Warszawa, pp. 559-631.

Rozner, I. and Rozner, Gy. (2008): Data to the leaf-beetle fauna of the Macedonia (Coleoptera, Chrysomelidae). Natura Somogyiensis, 12, 111-131.

Warchałowski, A. (1994): Chrysomelidae. Stonkowate, Tom IV (Insecta, Coleoptera) (Fauna Polski). Annals of Zoology, pp. 1-304.

Warchałowski, A. (2010): The palaearctic Chrysomelidae. Identification keys. Natura optima dux foundation, Warszawa, Vol. 1 and 2, pp. 1-1212. 